\title{
Rodrigo Guajardo ${ }^{1}$ \\ Systems Engineering Modelling and Simulation to Support Defence Acquisition System
}

\section{Rendszermérnöki modellezés és szimuláció a védelmi beszerzés rendszerének támogatására}

Modelling and Simulations have been applied in various engineering disciplines since the 1990s, especially in the area of defence, being an essential tool in all phases of the cycle of acquisition and in all applications whose main objective are to reduce the time, resources, and risks associated with acquisition, to enable the integrated product and process development, and to improve the quality of the fielded product. One of the main purposes of this research is to demonstrate the importance of Systems Engineering (INCOSE) as part of the defence acquisition system and how this engineering discipline has incorporated the use of Modelling and Simulations into their acquisition-cycle phases and processes.

Keywords: systems engineering, modelling, simulation, defence, acquisition.

A modellezést és a szimulációt az 1990-es évek óta alkalmazzák a műszaki tudományok területén, különösen a védelmi iparban, a beszerzési folyamat egyes szakaszaiban és minden olyan alkalmazás során, amelynél fontos, az elfogadható ár, a megfelelő minőség és a határidő betartása, valamint a kockázatok csökkentése. Így az integrált termék és folyamatfejlesztéssel lehetővé válik a késztermék minőségének a javítása. A tanulmány fő célja, a védelmi beszerzési rendszereken belül, a rendszertervezés (INCOSE) fontosságának a bemutatása, továbbá annak az elemzése, hogy a müszaki tudományterület milyen módon hasznosítja a modellezést és a szimulációt az életciklus-szemléleten keresztül a beszerzési folyamat egyes szakaszaiban.

Kulcsszavak: rendszerfejlesztés, modellezés, szimuláció, védelmi ipar, beszerzés 
Rodrigo Guajardo: Systems Engineering Modelling and Simulation...

\section{Introduction}

Before the industrial revolution, the development of complex systems was generally based on the results of lengthy trial and error processes, mainly through observation. The design and production of such systems can be characterised as lacking rigorous theoretical analysis. Indeed, the same might be said of some modern, large, complex systems. The absence of rigorous modelling and simulation made the designs more vulnerable to external influences that could not always be deflected adequately without detailed scientific evidence.

The continued development of mathematical and scientific knowledge in the $18^{\text {th }}$ and $19^{\text {th }}$ centuries, while facilitating great leaps forward in the complexity that could be achieved in complex systems - as in case of ships -, was still limited by the absence of appropriate tools to make full use of this knowledge. The ability to solve complex, non-linear and dynamic problems have stemmed directly from the advent of the digital computer, which provided mathematical and scientific theory with the enabling mechanism needed to model and simulate complex systems.

Modelling and simulation is a crucial enabler for mitigating the high risk involved in a complex system acquisition. ${ }^{2}$ While engineers of pre-industrial eras might have lacked the ability to make use of sophisticated, dynamic modelling and simulation, modern systems engineering has no such excuse. Modelling and simulation offer a mechanism for shortening time, increasing effectiveness, mitigating risk, and controlling cost. If modelling and simulation cannot deliver these benefits, it is of dubious value in system development. If a complex system is developed with inadequate levels of modelling and simulation, one cannot hope for a proper outcome.

Modelling and Simulation (M\&S) have long played an essential, although imperfect, role in system acquisition, operations, and support throughout the system life-cycle. Increasingly, capability concepts and system designs are defined by building models within the synthetic environments provided in systems and software engineering tools and computer-aided design (CAD) tools. M\&S helps manage complexity by tracking system characteristics, functions, relationships and interactions at the most granular level and then presenting aggregated impacts and higher-level measures of merit to decision-makers. System capabilities, processes, workloads, performance, logistics, and cost can be modelled. M\&S allows the immersion of warfighters in realistic operational environments to assess concepts, capabilities, and tactics. It can help explore the entire functional capability trade space.

Distributed simulation technology allows the flexible mixing of simulations, lab hardware, and real systems into an integrated environment in which integration and testing can be conducted. The effective acquisition requires collaboration among multiple stakeholders. M\&S are effective means of communication, facilitating shared understanding and insights among warfighters, sponsors, program staffs and industry at a much earlier point than would otherwise be possible. Thus M\&S tools linked as

Systems Engineering Fundamentals. Supplementary Text Prepared by the Defense Acquisition University Press, Fort Belvoir, Virginia, January 2001. Available: https://ocw.mit.edu/courses/aeronautics-and-astronautics/16-885j-aircraft-systems-engineering-fall-2005/readings/sefguide_01_01.pdf (24. 09. 2020.) 
needed, combined with an information-sharing infrastructure and put into a distributed collaborative environment can enable cost-effective development and sustainment of systems and systems of systems. If program circumstances (for instance, budgets, threats, technology) change, system design and support changes can be made rapidly, with all stakeholders able to play an appropriate role in those decisions.

The International Council on Systems Engineering (INCOSE ${ }^{3}$ ), in its October 2006 version of Systems Engineering Vision 2020, defines model-based systems engineering (MBSE) as 'the formalised application of modelling to support system requirements, design, analysis, verification and validation, beginning in the conceptual design phase and continuing throughout development and later life cycle phases. ${ }^{14}$

\section{Systems engineering basis}

\section{The definition of Systems Engineering (SE)}

Systems Engineering consists of two main areas or disciplines: the field of technical knowledge that is the environment of the systems engineer, and the area of systems engineering management.

Three used definitions of systems engineering are provided by the following technical standards that apply to this subject. They all have a common theme:

'Systems engineering is an interdisciplinary approach and means to enable the realisation of successful systems. It focuses on defining customer needs and required functionality early in the development cycle, documenting requirements, and then proceeding with design synthesis and system validation while considering the complete problem: operations, cost and schedule, performance, training and support, test, manufacturing, and disposal. ${ }^{15}$

'A logical sequence of activities and decisions that transforms an operational need into a description of system performance parameters and a preferred system configuration.' (MIL-STD ${ }^{6}-499 A,{ }^{7}$ Engineering Management, 1 May 1974. Replaced by ISO/IEC/IEEE 15288.1-2014 IEEE 'Standard for Application of Systems Engineering on Defence Programs'. ${ }^{8}$ )

3 'The International Council on Systems Engineering (INCOSE) is a not-for-profit membership organization founded to develop and disseminate the interdisciplinary principles and practices that enable the realization of successful systems. INCOSE is designed to connect SE professionals with educational, networking, and career advancement opportunities in the interest of developing the global community of systems engineers and systems approach to problems.' 'About INCOSE', INCOSE. Available: www.incose.org. (24. 09. 2020.)

4 Systems Engineering Vision 2020, INCOSE, 2007, 15. Available: www.ccose.org/media/upload/SEVision2020_ 20071003_v2_03.pdf (01. 11. 2020.)

5 INCOSE - Systems Engineering Handbook: A Guide for System Life Cycle Processes and Activities, ed. by David D. Walden (New Jersey: John Wiley \& Sons, 2015), 11.

6 MIL-STD: A United States defence standard, often called a military standard, 'MIL-STD', 'MIL-SPEC', or (informally) 'MilSpecs', is used to help achieve standarisation objectives by the U.S. Department of Defense.

7 MIL-STD 499A:1974 Military Standard: Engineering Management, U.S., Department of Defense. Available: http://everyspec.com/MIL-STD/MIL-STD-0300-0499/MIL-STD-499A_10375/ (11. 11. 2019.)

8 'Department of Defense Instruction 5000.02 (DoDI)', U.S. Department of Defense, Washington DC, 2015. Available: http://acqnotes.com/wp-content/uploads/2014/09/DoD-Instruction-5000.2-Operation-of-the-AdaptiveAcquisition-Framework-23-Jan-2020.pdf (15. 11. 2019.) 
'The set of activities which control the overall design, implementation and integration of a complex set of interacting components or systems to meet the needs of all users and other stakeholders. ${ }^{19}$

\section{Systems engineering origins and standardisation}

Systems engineering is one of the main pillars of the defence acquisition process in the U.S., U.K. and NATO. As for the technical management, its practices can ensure increased confidence in the forecast cost, time and performance of the system and the right balance of investment between the cost of acquiring new equipment and that of supporting in-service equipment can be achieved. Additionally, these practices provide the armed forces with the right capabilities to enable them to complete the tasks required of them.

Systems engineering 'came into its own in the mid- $20^{\text {th }}$ century, driven by the military technological competition of the Second World War and the cold war. Scientists, engineers and managers from industry and academia developed new weapons for their military patrons, including atomic and hydrogen bombs, jet fighters, ballistic missiles, strategic defence command and control systems, and reconnaissance satellites. Faced with extraordinary demands to create and deploy novel, complex systems at a rapid pace, these three groups produced new techniques to manage the diversity and scale of information and technology. Each group developed its approach: scientists created operations research, engineers created systems engineering, and managers created project management. Each approach reflected the efforts of a specific knowledge community to cope with the complexities of large technological systems. ${ }^{10}$

Operations research, systems engineering, and project management, were at home in the world of broad research and development organisations, particularly those of the Department of Defense (DOD) and its contractors. All three of these new 'disciplines' had distinct roles in the development of procedures for military $R \& D$. They coordinated the activities of other groups through mathematical analysis, engineering coordination, and managerial control, using borrowed mathematical and theoretical methods. Each paid close attention to the processes of R\&D and developed procedures to control the information and interrelationships among analysis, design, and testing.

Most of the mathematical methods used in these disciplines were applications of existing practice to new problems; probability and statistics, queuing theory, symbolic logic, and matrix techniques existed long before their application to engineering systems. Some, such as game theory, information theory, and feedback control theory, were relatively new, but developed before and separately from operations research and systems engineering.

9 The Acquisition Handbook. Ministry of Defence, 2002. Available: www.defence.org.cn/aspnet/vip-usa/uploadfiles/2004102932134509.pdf (11.11.2019).

10 Stephen Johnson, 'Three approaches to big technology: Operations research, systems engineering, and project management', Technology and Culture 38, no 4 (1997), 891-919. 
The essence of these new disciplines lay not in their borrowed mathematical methods but rather in the functions they performed in research and development. Each specialised in the creation and application of what shall be called procedural knowledge, academically problematic but practically useful. Project managers imposed a new organisational structure and process controls. Systems engineers created a new engineering function devoted to communication processes and documentation across disciplinary boundaries. Some operations researchers transformed their methods into systems analysis, a set of practices for comparing design and operational options for future technologies. Together, these techniques formed 'systems management', as shown in Figure 1, the military-industrial method for developing new, large-scale technological systems.

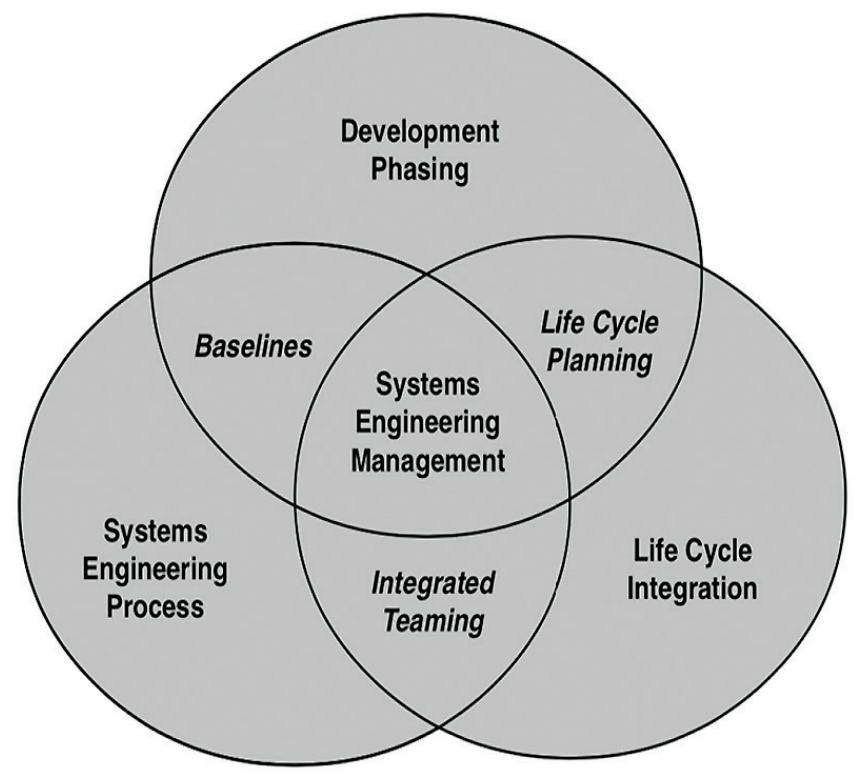

Figure 1

Main activities of Systems Engineering Management.

Source: Systems Engineering Fundamentals.

Systems management and its component techniques were essential elements of the 'systems approach', an important intellectual development of the 1950s and 1960s with strong proponents in academia as well as the military-industrial complex. Despite its critics, systems management became the standard method of organising R\&D in the aerospace industry, spreading later to other industries in the United States and other countries throughout the world. After the war, system integration spread to become a new standard for government-industry interaction. Along with the conception that the integrated system as a whole is more significant than the sum of its parts, it formed a crucial element in what was to become the new discipline of systems engineering. 
The modern origins of SE can be traced back to the 1930s and were followed quickly by other programs and supporters. Table $1 \mathrm{highlights} \mathrm{some} \mathrm{crucial} \mathrm{milestones}$ in the origins of Systems Engineering; a list of current significant Systems Engineering standards and guides is provided in Table 2.

Table 1

Important dates in the origins of SE as a discipline.

Source: INCOSE - Systems Engineering Handbook, 12.

\begin{tabular}{|l|l|}
\hline 1937 & British multidisciplinary team to analyse the air defence system \\
\hline $1939-1945$ & Bell Labs supported NIKE missile project development \\
\hline $1951-1980$ & $\begin{array}{l}\text { SAGE air defence system defined and managed by Massachusetts Institute of } \\
\text { Technology (MIT) }\end{array}$ \\
\hline 1954 & Recommendation by the RAND Corporation to adopt the term 'systems engineering'. \\
\hline 1956 & Invention of systems analysis by RAND Corporation \\
\hline 1962 & Publication of A Methodology for Systems Engineering by Hall \\
\hline 1969 & Modelling of urban systems at MIT by Jay Forrester \\
\hline 1990 & National Council on Systems Engineering (NCOSE) established \\
\hline 1995 & INCOSE emerged from NCOSE to incorporate international view \\
\hline 2008 & $\begin{array}{l}\text { ISO, IEC, IEEE, INCOSE, PSM, and others fully harmonise SE concepts on ISO/IEC/ } \\
\text { IEEE 15288:2008 }\end{array}$ \\
\hline
\end{tabular}

Due to the mission of the U.S. Department of Defense (DoD) in the acquisition and development of highly complex systems on a large production scale, defence procurement managers decided to standardise and codify the systems engineering process by publishing the Military Standard 499 (MIL-STD 499), which decision had a deep impact on the early development of the discipline and its standardisation processes. DoD's officials approved a later revision of the military standard (MIL-STD 499A) for Air Force use only (DoD). However, MIL-STD 499A quickly became the Systems Engineering standard for many defence acquisition programs. The Systems Engineering process model included: Mission requirements analysis, functional analysis, and allocation and synthesis, as is presented in Figure 2.

Table 2

Current significant SE standards and guides.

Source: INCOSE - Systems Engineering Handbook, 13.

\begin{tabular}{|l|l|}
\hline ISO/IEC/IEEE 15288:2015 & Systems and software engineering - System Life Cycle Processes \\
\hline IEEE 15288.1-2014 & IEEE Standard for Application of Systems Engineering on Defence Programs \\
\hline IEEE 15288.2-2014 & IEEE Standard for Technical Reviews and Audits of Defence Programs \\
\hline ISO/IEC/IEEE 15289:2015 & Content of systems and software life cycle information products \\
\hline ISO/IEC TR 24748-1:2010 & Guide for Life Cycle Management \\
\hline ISO/IEC TR 24748-2:2011 & Guide for Application of 15288 \\
\hline ISO/IEC TR 24748-3:2011 & Guide for Application of 12207 \\
\hline ISO/IEC 15504:2004 & Information Technology - Process Assessment \\
\hline
\end{tabular}


Rodrigo Guajardo: Systems Engineering Modelling and Simulation...

\begin{tabular}{|l|l|}
\hline ISO/PAS 19450:2015 & Automation systems and integration - Object-Process Methodology (OPM) \\
\hline ISO 10303-AP233 & Industrial automation systems and integration \\
\hline ANSI/GEIA EIA-632 & Processes for Engineering a System \\
\hline EIA/IS 731.1 & Systems Engineering Capability Model, Electronic Industries Alliance \\
\hline IEEE 1220-2005 & $\begin{array}{l}\text { IEEE Standard for Application and Management of the Systems } \\
\text { Engineering Process }\end{array}$ \\
\hline ANSI/AIAA G-043-1992 & Guide for the Preparation of Operational Concept Documents \\
\hline IEEE 1471, 2000 & $\begin{array}{l}\text { IEEE Recommended Practice for Architectural Description of Software- } \\
\text { Intensive Systems }\end{array}$ \\
\hline ISO 10303-AP243 & $\begin{array}{l}\text { MoSSeC (Modelling and Simulation information in a Collaborative } \\
\text { Systems Engineering Context) }\end{array}$ \\
\hline ISO 31000 & Risk management - Principles and guidelines \\
\hline SEBoK & Guide to the systems engineering body of knowledge \\
\hline
\end{tabular}

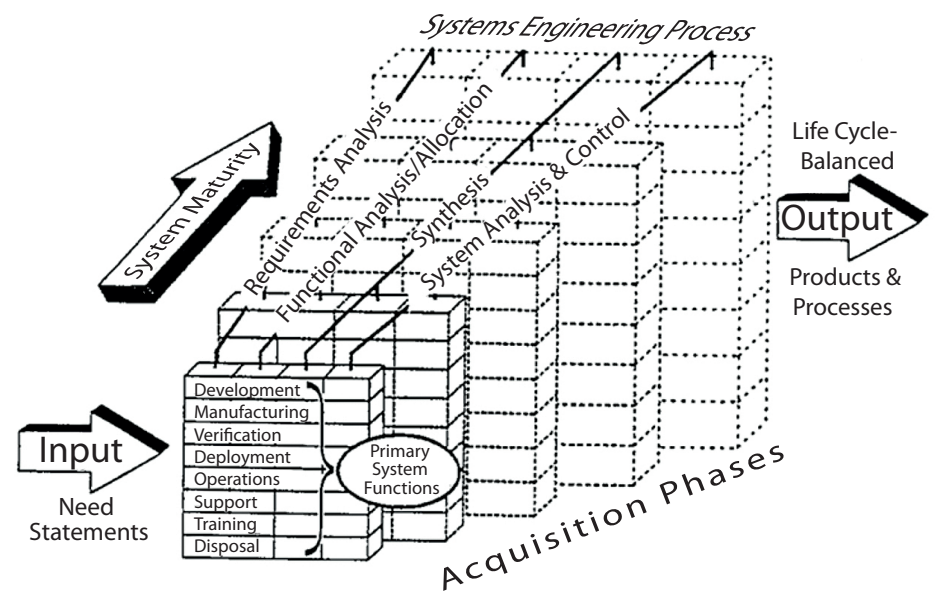

Figure 2

Systems Engineering's Life-Cycle Application.

Source: MIL-STD 499A:1974.

MIL-STD 499A was expanded and updated as MIL-STD 499B 'Systems Engineering' draft. The Air Force Materiel Command sponsored a working group formed to review and revise MIL-STD 499A for use by all DoD components, federal agencies, and commercial organisations. The purpose of the new standard was to define a comprehensive, executable process that would result in optimal system solutions while meeting cost, schedule, and performance objectives. The drafters claimed that the revised standard would achieve critical DoD acquisition reform efforts to encourage innovation in products and practices, to integrate requirements through multi-disciplinary teamwork, to increase teamwork and cooperation within the government and industry, and to reduce the time needed to acquire products and services. However, it was never formally published and approved by DoD officials due to another acquisition reform initiative that emphasised the use of commercial standards over government standards. 
As a consequence of introducing the international standard ISO/IEC ${ }^{11} 15288$ in 2002, the discipline of SE was formally recognised, and the MIL-STD 499 was cancelled. This standard is a systems engineering standard developed by SE experts from government, industry, and academia, being recognised by both industry and the Department of Defense (DoD) as being a common framework to improve the effectiveness of systems engineering throughout the system life cycle. IEEE 15288.12014 was adopted on 5 June 2015 for use by the U.S. Department of Defense (DoD) as a replacement, providing the basis for selection, negotiation, agreement, and performance of critical systems engineering activities and delivery of products.

As stated, the U.S. Deputy Assistant Secretary of Defense for Systems Engineering about the importance of standardisation:

'Technical standards provide the corporate process memory needed for a disciplined system engineering approach and help ensure that the government and its contractors understand the critical processes and practices necessary to take a system from design to production, and through sustainment'. ${ }^{12}$

The main goal of implementing the IEEE 15288.1 standard was to provide U.S. and U.S. DoD contractors a structured and uniform procedure in the areas identified as weakness, improving communication, ensuring common expectations and adding realism to bids.

\section{The defence acquisition system and the systems engineering process}

\section{Defence Acquisition System}

The Defence Acquisition System has its foundation in the country's public law and policies (ministerial directives, instructions and manuals, service regulations and inter-service and international agreements), they govern the development, acquisition, operation and disposal of military systems. Managing the development and fielding of military systems requires three necessary activities: technical management, business management and contract management. In countries as the U.S. and the U.K., among others, Systems Engineering Management is one of the main pillars and it has to deal with the technical management component of MoD acquisition management at DAU ${ }^{13}(2000) .^{14}$

In the United States, the U.S. DoD 5000 defence acquisition documents were revised in 2000 to make a more flexible process, introducing advanced technology to warfighters more rapidly and at reduced total ownership cost. The new process encourages multiple entry points, depending on the maturity of the fundamental technologies involved, and the use of evolutionary methods to define and develop

11 ISO/IEC International Organization for Standardization / International Electrotechnical Commission.

12 Stephen P. Welby, 'Standards', MES Journal 8 (2013), 2-3. Available: www.msco.mil/DocumentLibrary/Journals/MSJournalSpring2013.pdf (15. 11. 2019.)

13 DAU: Defence Acquisition University (DAU), corporate university of the United States Department of Defense, offering 'acquisition, technology, and logistics' (AT\&L) training to military and Federal civilian staff and Federal contractors.

14 Systems Engineering Fundamentals, Supplementary Text Prepared by the Defense Acquisition University Press, Fort Belvoir, Virginia, January 2001. Available: https://ocw.mit.edu/courses/aeronautics-and-astronautics/16-885j-aircraft-systems-engineering-fall-2005/readings/sefguide_01_01.pdf (24. 09. 2020.) 
systems encouraging a tailored approach to acquisition and systems engineering management. However, it does not alter the basic logic of the underlying systems engineering process. Later on, in $2015,{ }^{15}$ one of the significant changes happened in the revised acquisition system, with an increased emphasis on systems engineering tools and techniques as simulation and modelling (S\&M), alternative analysis and trade-offs analysis made between capability requirements and life cycle costs in the early stages of the acquisition process; these ensure that realistic program baselines are established.

\section{Systems Engineering Process (SEP)}

Systems Engineering Process (SEP) is an iterative, recursive and comprehensive problem-solving process. It transforms needs and requirements into process descriptions and the final system product, generating the required information for decision-makers, providing inputs for the next stage. The SEP is applied sequentially, adding additional details and definitions with each level of development.

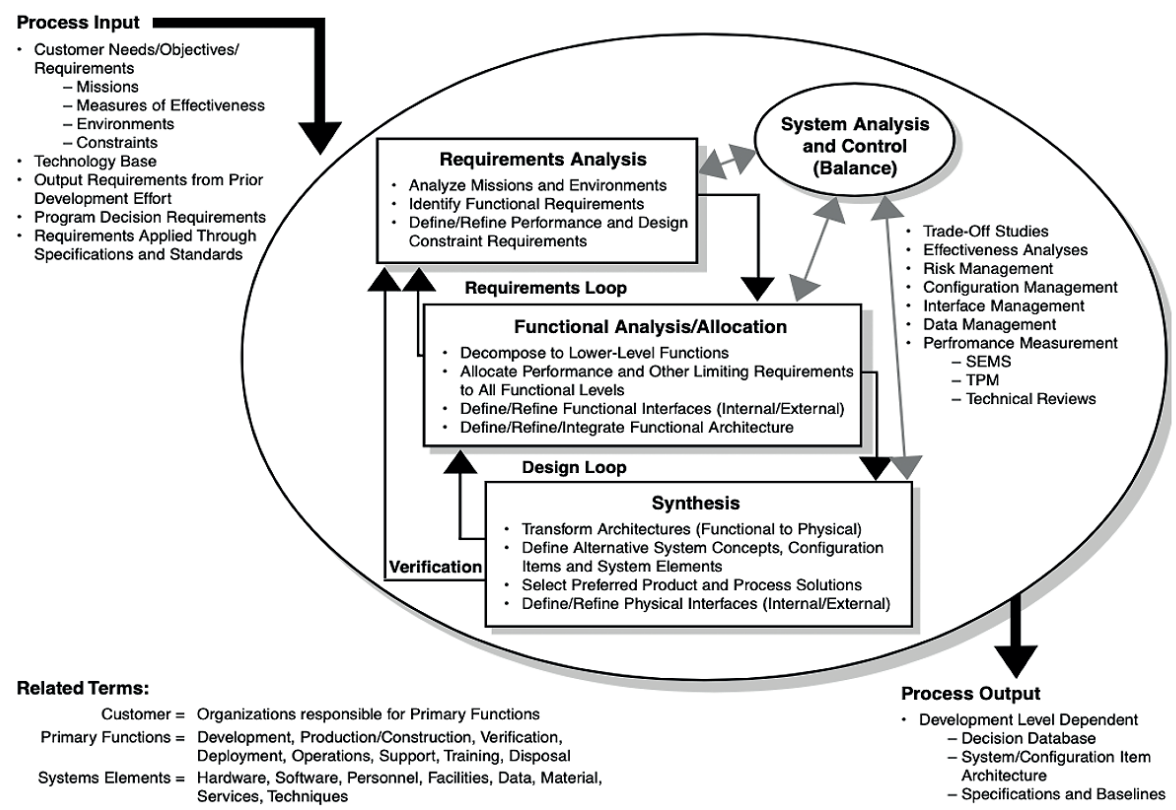

Figure 3

Systems Engineering Process (SEP).

Source: Systems Engineering Fundamentals.

As shown by Figure 3, the SEP includes requirements analysis, functional analysis and allocation, requirements loop, synthesis, design loop, verification, system analysis and control, and finally the process inputs and outputs as detailed below:

15 'Department of Defense Instruction'. 
Systems Engineering Process Inputs:

Inputs consist primarily of the end user's needs, objectives, requirements and project constraints. Inputs can include missions, environments, measures of effectiveness, available technology, output requirements from the prior application of the SEP, program decision requirements, and requirements based on 'organisation knowledge'.

\section{Requirements Analysis:}

The initial step of the SEP is to analyse the process inputs. Requirements analysis support in the development of functional and performance requirements 'translates' the user/ customer requirements. These must be understandable, comprehensive, complete, concise, and unambiguous, defining what the system must do and how it must perform.

Requirements analysis must clearly define the functional requirements and design constraints. Functional requirements define quality (how good), quantity (how many), coverage (how far), timelines (when and how long), and availability (how often). Constraints in the design stage define those factors that limit design flexibility, customer or regulatory standards, such as environmental conditions, internal or external threats, and contract.

\section{Functional Analysis/Allocation:}

Functions are analysed by decomposing higher-level functions into lower-level functions, resulting in a description in terms of what the product should logically do and what the performance needed. Functional analysis and allocation allow for a better understanding of what the system has to do, as presented in Figure 4. Functional flow, block diagrams, timeline analysis, and the requirements allocation sheet are some essential tools in this part of the process.

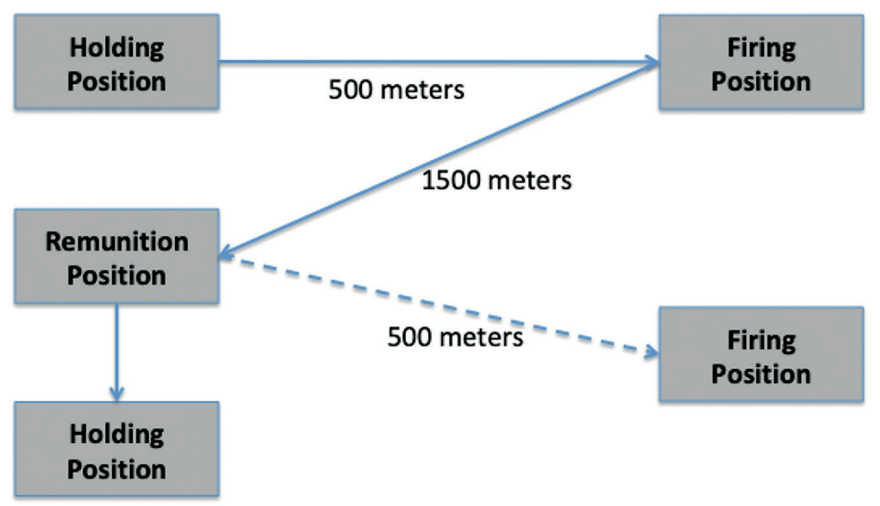

Figure 4

Example of a functional diagram for a single mission of a Rocket Artillery System. Source: created by author. 
Requirements Loop:

The Requirements Loop allows to refine and initiate the re-evaluation of the requirements to determine its firmness. Performance of the functional analysis results in a better understanding of the requirements; each function identified should be traceable back to the corresponding requirement. This iterative process of revisiting requirements analysis is known as the requirements loop.

\section{Design Synthesis:}

This is the process of defining the product or components in terms of the physical/ software elements which together define the system; the final result is known as the physical architecture. The physical architecture is the base structure in order to generate the specifications and baselines. Figure 5 presents a sample of a generic weapon system's physical architecture.

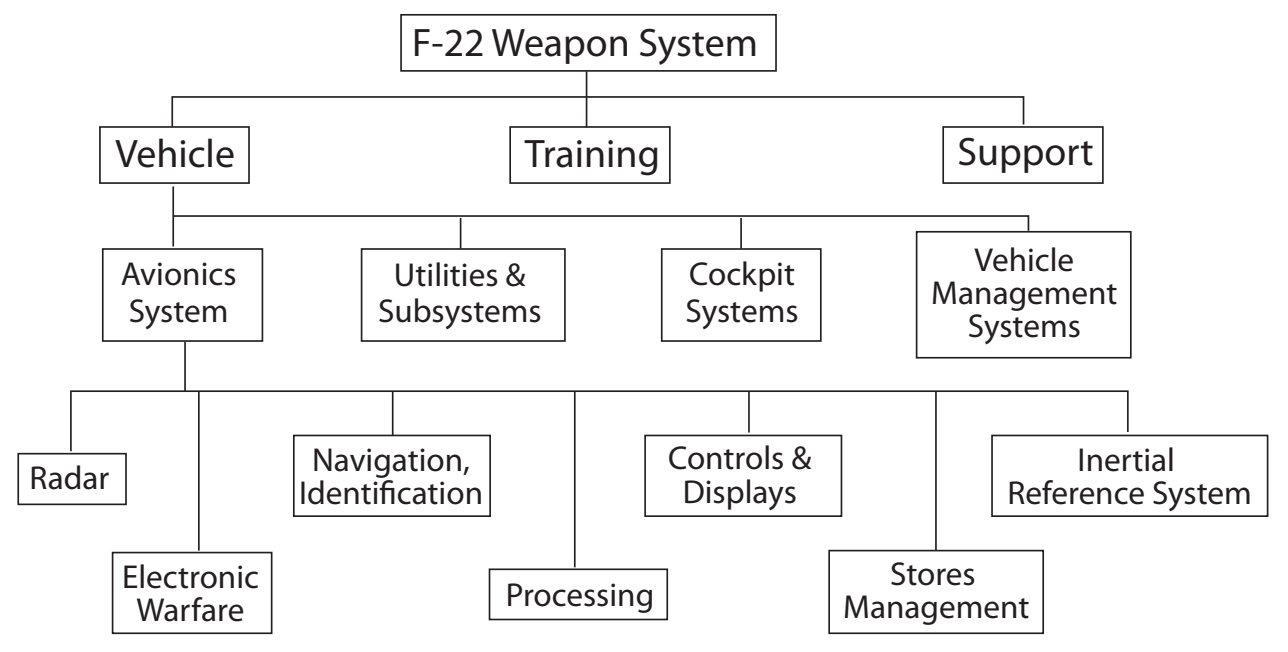

Figure 5

Sample of a generic weapon system's physical architecture.

Source: Dennis M. Buede, The Engineering Design of Systems - Models and Methods (New Jersey: John Wiley \& Sons, 2009), 28.

\section{Design Loop:}

Similar to the requirements loop mentioned before, the design loop is the process of revisiting the functional architecture in order to verify that the physical design can carry out the required functions with the required levels of efficiency. The design loop permits to reconsider how the system will perform its mission, and this helps to optimise the synthesised design. 
Verification:

The final solution will be compared to the requirements for each application of the system engineering process. This part of the process is called 'verification' (see Figure 6). Each requirement at each level must be verifiable. Baseline documentation elaborated during the systems engineering process must define the method of verification for each requirement.

Some verification methods include, among others, examination, demonstration, analysis (including modelling and simulation), and testing. Formal test and evaluation are significant contributors to the verification of systems.

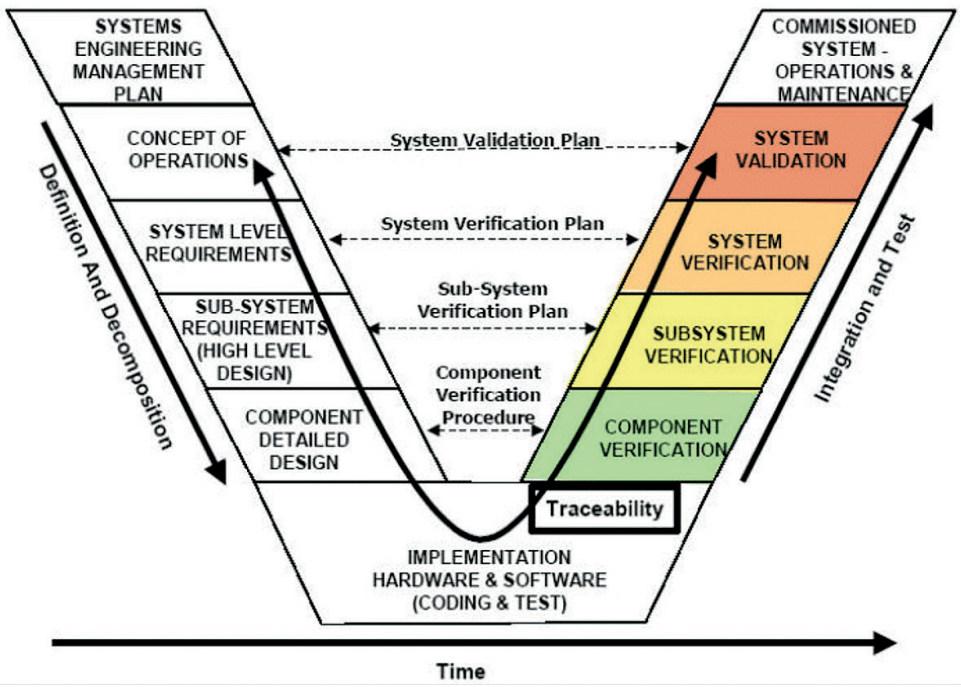

Figure 6

Sample of a Systems Engineering "V" (Verification) diagram.

Source: Elie Allouis, R. Blake, S. Gunes-Lasnet, T. Jorden, B. Maddison, H. Schroeven-Deceuninck, M. Stuttard, P. Truss, K.Ward, R. Ward and M. Woods, 'A Facility for the Verification \& Validation of Robotics \& Autonomy for Planetary Exploration'. Proceedings of the 12th Symposium on Advanced Space Technologies in Automation and Robotics. Noordwijk, ASTRA, 2013. Available: http://robotics.estec.esa.int/ASTRA/Astra2013/Papers/ Allouis_2824264.pdf (28.04.2020.)

\section{Systems Analysis and Control:}

Systems Analysis and Control concern the technical management activities necessary to monitor the progress, to analyse of alternatives, and document the data and decisions.

System analysis concerns design, trade-off and effectiveness analyses. They evaluate an alternative that satisfies technical requirements and program objectives, providing a strong quantitative base for selecting performance, functional and design requirements. To provide input to analysis, the tools to be used include modelling, simulation, experimentation, and testing.

Control activities include risk management, configuration management, data management, and performance-based progress measurement, including event-based scheduling, Technical Performance Measurement (TPM), and technical reviews. 


\section{Acquisition system life cycle}

According to NATO AAP-48:2013 ${ }^{16}$ and ISO/IEC/IEEE $15288: 2015,^{17}$ every system has a life cycle. A life cycle can be decomposed into a set of stages consisting of processes and activities. The system progresses through these stages as the result of actions, performed and managed by people in organisations. NATO has decided to follow ISO/IEC/IEEE 15288:2015, which covers processes and life cycle stages in dividing the whole system life cycle into six stages, as presented in Figure 7: 1. Concept; 2. Development; 3. Production; 4. Utilisation; 5. Support; 6. Retirement. Each stage represents one essential period of the life cycle of a system. The partitioning of the system life cycle into stages is based on the practicality of doing the work in small, understandable, timely steps. Stages also help address uncertainties and risk associated with cost, schedule, and general objectives and decision making. Each stage has a well-defined purpose and contribution to the whole life cycle. The transition between stages uses decision gates and entry/exit criteria.

Generic life cycle (ISO/IEC/IEEE 15288:2015)

\begin{tabular}{|c|l|l|l|l|}
\hline & Development \\
stage & Production & Utilization stage & \multirow{2}{*}{$\begin{array}{c}\text { Retirement } \\
\text { stage }\end{array}$} \\
\cline { 4 - 4 } & & stage & Support stage & \\
\hline
\end{tabular}

Typical high-tech commercial systems integrator

\begin{tabular}{|c|c|c|c|c|c|c|c|c|c|}
\hline \multicolumn{4}{|c|}{ Study period } & \multicolumn{3}{|c|}{ Implementation period } & \multicolumn{3}{|c|}{ Operations period } \\
\hline $\begin{array}{c}\text { User } \\
\text { requirements } \\
\text { definition } \\
\text { phase }\end{array}$ & $\begin{array}{l}\text { Concept } \\
\text { definition } \\
\text { phase }\end{array}$ & $\begin{array}{c}\text { System } \\
\text { specification } \\
\text { phase }\end{array}$ & $\begin{array}{c}\text { Acq } \\
\text { prep } \\
\text { phase }\end{array}$ & $\begin{array}{l}\text { Source } \\
\text { select. } \\
\text { phase }\end{array}$ & $\begin{array}{l}\text { Development } \\
\text { phase }\end{array}$ & $\begin{array}{c}\text { Verification } \\
\text { plase }\end{array}$ & $\begin{array}{c}\text { Deployment } \\
\text { phase }\end{array}$ & $\begin{array}{c}\text { Operations and } \\
\text { maintenance } \\
\text { phase }\end{array}$ & $\begin{array}{c}\text { Deactivation } \\
\text { plase }\end{array}$ \\
\hline
\end{tabular}

Typical high-tech commercial manufacturer

\begin{tabular}{|c|c|c|c|c|c|c|c|c|}
\hline \multicolumn{3}{|c|}{ Study period } & \multicolumn{3}{|c|}{ Implementation period } & \multicolumn{3}{|c|}{ Operations period } \\
\hline $\begin{array}{l}\text { Product } \\
\text { requirements } \\
\text { phase }\end{array}$ & $\begin{array}{l}\text { Product } \\
\text { definition } \\
\text { phase }\end{array}$ & $\begin{array}{l}\text { Product } \\
\text { development } \\
\text { phase }\end{array}$ & $\begin{array}{l}\text { Engr. } \\
\text { model } \\
\text { phase }\end{array}$ & $\begin{array}{l}\text { Internal } \\
\text { test } \\
\text { phase }\end{array}$ & $\begin{array}{l}\text { External } \\
\text { test } \\
\text { plasse }\end{array}$ & $\begin{array}{l}\text { Full-scalc } \\
\text { production } \\
\text { phase }\end{array}$ & $\begin{array}{c}\text { Manufacturing, } \\
\text { sales, and } \\
\text { support phase }\end{array}$ & $\begin{array}{c}\text { Deactivation } \\
\text { phase }\end{array}$ \\
\hline
\end{tabular}

US Department of Defense (DoD)

\begin{tabular}{|c|c|c|c|c|c|}
\hline $\begin{array}{c}\text { User } \\
\text { needs }\end{array}$ & Pre-sustel & & Systems & IOC & \begin{tabular}{|l|l|} 
FOC \\
\end{tabular} \\
\hline $\begin{array}{c}\text { Tech } \\
\text { opport } \\
\text { resources }\end{array} \mid$ & $\begin{array}{l}\text { Matericl } \\
\text { solution } \\
\text { analysis }\end{array}$ & $\begin{array}{l}\text { Technology } \\
\text { development }\end{array}$ & $\begin{array}{c}\text { Engineering and } \\
\text { manufacturing } \\
\text { development }\end{array}$ & $\begin{array}{c}\text { Production and } \\
\text { deployment }\end{array}$ & $\begin{array}{l}\text { Opcrations and support } \\
\text { (including disposil) }\end{array}$ \\
\hline
\end{tabular}

National Aeronautics and Space Administration (NASA)

\begin{tabular}{|c|c|c|c|c|c|c|}
\hline \multicolumn{2}{|c|}{ Formulation } & \multicolumn{2}{|c|}{ Approval } & \multicolumn{2}{|l|}{ Implementation } & \multirow[b]{2}{*}{$\begin{array}{l}\text { Phase Fs } \\
\text { closeout }\end{array}$} \\
\hline $\begin{array}{l}\text { Pre-phase A: } \\
\text { concept studies }\end{array}$ & $\begin{array}{c}\text { Phase A: } \\
\text { conoep \& Ecchology } \\
\text { development }\end{array}$ & \begin{tabular}{|c|} 
Phare B: \\
preliminary design \& \\
technology completion \\
\end{tabular} & $\begin{array}{c}\text { Phase C: } \\
\text { final design \& } \\
\text { fabrication }\end{array}$ & \begin{tabular}{|c|} 
Phase D: \\
system assembly \\
integration \& est, launch \\
\end{tabular} & $\begin{array}{c}\text { Phase E: } \\
\text { operations \& } \\
\text { sustainment }\end{array}$ & \\
\hline
\end{tabular}

Figure 7

ISO/IEC/IEEE 15288:2015 and its comparisons with other life cycle models.

Source: INCOSE - Systems Engineering Handbook.

16 NATO AAP-48:2013 System Life Cycle Processes.

17 ISO/IEC/IEEE 15288:2015 International Standard - Systems and software engineering - System life cycle processes. 


\section{Concept Stage:}

The concept stage begins with some recognition of a need for a new or modified system of interest (SOI). Many industries employ an exploratory research activity in the concept stage to study new ideas or enabling technologies and capabilities, which then mature into the new project initiation (for the SOI). Often, the exploratory research activity identifies the enabling technologies. If the work is done correctly in the early stages, it is possible that future iterations can be reduced or avoided in subsequent stages. Many life cycle models show the process of beginning with 'requirements' or 'user requirements'. The process begins earlier with interactions and studies to understand potential new organisational capabilities, opportunities, or stakeholder needs. It is critical that in these early studies, a high-level, preliminary concept be created and explored to whatever depth is necessary to identify technical risks and to assess the technology readiness level (TRL) of the project. The focus is on studying potential technologies and determining the state of what is possible and what is not. In some instances, the project may be an outgrowth of research activities where the research engineer or scientist has no connection to a user-supported need. The preliminary concept and enabling technologies need to be identified early. One of the challenges in developing alternate concepts is that we often build on what has worked well for us in the past, without considering valid alternatives, and thereby we miss opportunities to make much better improvements. The preliminary concept will also be used to forecast initial cost and schedule projections for the project if it moves ahead. Incomplete SE in this stage can lead to poor cost and schedule projections, as well as poor understanding of technical alternatives, resulting in poor trades among the alternatives. The preliminary concept is a starting point, not an endpoint, as the project moves into the concept selection activity of the concept stage.

Concept selection is the second activity of the concept stage. The concept selection activity is a refinement and broadening of the studies, experiments, and engineering models pursued during the exploratory research activity. First of all one has to identify, make clear, and document the stakeholders' conceptual operation of the system through the different stages of utilisation, and the environments intended to be used. The operational concept (OpsCon) effort should be undertaken to include any changes caused by changes in the manufacture processes or materials, changes in interface standards or new feature enhancements being added; these can drive various aspects of concept selection of the system.

These studies extend the evaluation of risk and opportunity, including failure modes, affordability assessment, environmental impact, hazard analysis, technical obsolescence, and system disposal analysis.

\section{Development Stage:}

The development stage defines and realises a system of interest (SOI) that meets its stakeholder requirements and that can be produced, utilised, supported, and retired. The development stage begins with the outputs of the concept stage. The 
primary output of this stage is the SOI. Other outputs can include the SOI prototype, enabling system requirements (or the enabling systems themselves), system documentation, and cost estimates for future stages. Business and mission needs, along with stakeholder requirements, are refined into system requirements. These requirements are used to create a system architecture and design. The concept from the previous stage is refined to ensure that all system and stakeholder requirements are satisfied. Requirements for production, training, and support facilities are defined. Enabling systems' requirements and constraints are considered and incorporated into the design. System analyses are performed to achieve system balance and to optimise the design for critical parameters.

\section{Production Stage:}

The production stage is where the system is produced or manufactured. Modifications to the initial product may be required to resolve production problems, to reduce production costs, or to enhance product or system capabilities.

\section{Utilisation Stage:}

The utilisation stage is where the system is operated in its intended environment to deliver its intended services. Product changes are usually planned for introduction throughout the operation of the system. These upgrades intend to enhance the capabilities of the system. Systems engineers intend to ensure that smooth integration with the operating system should assess these changes. For large complex systems, midlife upgrades can be substantial endeavours requiring SE effort equivalent to a significant program.

\section{Support Stage:}

The support stage is where the system is provided with services that enable continuous operation. Modifications may be proposed in order to solve supportability problems, reduce operational costs, or to extend the system's life. These changes require SE assessment to avoid loss of system capabilities while under operation.

\section{Retirement Stage:}

The retirement stage is where the system and its related services are removed from operation. SE activities in this stage are primarily focused on ensuring that disposal requirements are satisfied. Planning for retirement is part of the system definition during the concept stage. Experience has repeatedly demonstrated the consequences when system retirement is not considered from the outset. 
The whole life cycle approach finally will allow for the defence acquisition system to have more accurate visibility and prediction of activities, time and costs that will be very important to reduce the uncertainties and inherent risks associated with new product development programs.

\title{
Modelling and simulation in support of the defence acquisition system
}

\author{
Modelling and Simulation (MES)
}

Stakeholders of the SE life cycle have used models and simulations for some time both to check their thinking and to communicate their concepts to others. The benefit is double: (i) models and simulations confirm the need for the systems and the expected system behaviours before proceeding with the development of an existing system, and (ii) models and simulations present a straightforward, coherent design to those who will develop, test, deploy, and evolve the system, thereby maximising productivity and minimising error. ${ }^{18}$ The ability to detect limitations and incompatibilities via system models and simulations early in a project helps avoid higher project cost and schedule overruns later in a project, especially during system operation. The value of modelling and simulation increases with the size - be it physical size or complexity - of the system or system under development.

Early in the SE life cycle, the objective of modelling and simulation is to obtain information about the system before significant resources are committed to its design, development, construction, verification, or operation. To that end, modelling and simulation help generate data in the domain of the analyst or reviewer, not available from existing sources, in a manner that is affordable and timely to support decision making. An adequate, accurate, and timely model and simulation informs stakeholders about the implications of their preferences, provides perspective for evaluating alternatives, and builds confidence in the capabilities the system will provide. They also help the development, deployment, and operational staffs comprehend the design requirements, appreciate imposed limits from technology and management, and ensure an adequate degree of sustainability. Finally, adequate, accurate, and timely models and simulations help the organisation and its suppliers provide the necessary and sufficient personnel, methods, tools, and infrastructure for system realisation.

The long-term benefits of modelling and simulation are commensurate with the gap between the extent, variety, and ambiguity of the problem and the competencies of downstream staffing. A relatively simple model of an intended system may be sufficient for highly competent staff. In contrast, a much more elaborate simulation may be necessary for less competent staff, especially one faced with producing a novel, large-scale system that is capable of autonomously coping with unpredictable mission situations. Ultimately, the benefit of modelling and simulation is proportional to the stakeholders' perception of the timeliness, trustworthiness, and ease of use

18 Modeling and Simulation in Manufacturing and Defense Acquisition: Pathways to Success. National Research Council (Washington DC: The National Academies Press, 2002). 
and maintenance of the model or simulation. Consequently, the planned resources anticipated to be spent in development, verification, validation, accreditation, operation, and maintenance of the model must be unvarying with the expected value of the information obtained through the use of the model.

\section{The purpose of system modelling}

System models can be utilised for many purposes. One of the first principles of modelling is to define the purpose of the model clearly. Some of the purposes of those models throughout the system life cycle include:

\section{Characterising an existing system:}

Many existing systems are poorly documented, and modelling the system can provide a concise way to capture the existing system architecture and design. This information can be used later to facilitate maintaining the system or to assess the system to improve it. This is analogous to creating an architectural model of an old building with overlays for electrical, plumbing, and structure before proceeding to upgrade it to new standards to withstand earthquakes.

\section{Mission and system concept formulation and evaluation:}

Early in the system life cycle, models can be applied to synthesise and evaluate mission and system concepts of the alternative. Models can be used to explore a trade space by modelling alternative system designs and evaluating the criticality of system parameters such as weight, speed, accuracy, reliability, and cost on the overall measures of merit. In addition to bounding the system design parameters, models can also be used to validate that the system requirements meet stakeholder needs before proceeding with later life cycle activities such as architecting and design.

System architecture design and requirements flow-down:

Models can be used to support the system solutions, as well as flow missions and system requirements down to system elements. Different models may be required to assess different aspects of the system design requirements. This may include models that specify functional, interface, performance, and physical requirements, as well as other non-functional requirements such as reliability, maintainability, safety, and security. 
Support for systems integration and verification:

Models can be used to support the integration of the hardware and software elements into a system, as well as to support verification of the system's requirements achievement. This often involves integrating lower level hardware and software design models with system level design models, which verify that the system requirements are satisfied. Systems integration and verification may also include replacing selected hardware and design models with actual hardware and software products to verify that the system requirements are satisfied incrementally. This is referred to as hardware-in-the-loop testing and software-in-the-loop testing. Additionally, models can be used to define the test cases and other aspects of the test program to assist in test planning and execution.

\section{Support for training:}

Models can be used to simulate many aspects of the system to help train users to interact with it. Users may be operators, maintainers, logistics or other stakeholders. Models may be the base for developing a simulator of the system with different levels of fidelity to represent user interaction in different operational scenarios.

\section{Knowledge capture and system design evolution:}

Models provide an effective way of capturing knowledge about the system and retaining it. This knowledge, which can be reused and updated, provides a basis for supporting the development of the system, such as modifying system requirements in the face of emerging, relevant technologies, new applications, and new customers.

Models represent the essential characteristics of the system of interest (SOI), the environment in which the system operates, and the interactions with enabling and interfacing systems and operators. Models and simulations can be used within most system life cycle processes.

\section{Business or mission analysis:}

A descriptive model of the problematic situation ensures that the right problem(s) is being addressed.

Requirements (stakeholder and system) definition:

It enables justification of requirements and avoids over-/underspecification. 


\section{Architecture definition:}

This means evaluation of candidate options against selection criteria and enabling active agents to discover the best architecture, including the integration to other systems.

\section{Design definition:}

This means obtaining the needed design data, adjusting parameters for optimisation, and updating system model fidelity as actual data for system elements to become available.

\section{Verification and validation:}

This means simulating the system's environment, evaluating verification and validation data (simulation uses observable data as inputs for computation of critical parameters that are not directly observable), and validating the fidelity of the simulation (false positives/false negatives).

\section{Operations:}

These mean simulations that reflect actual behaviour and simulation of operations in advance of execution for planning, validation, and operator training.

\section{Modelling and Simulation (MES) in Defence Acquisition Lifecycle}

The use of modelling and simulation (M\&S) is not new in defence acquisition. In the 1960 s, as computing capabilities increased, the task of modelling and simulating both the design and performance of defence systems moved increasingly toward digital representations and algorithms implemented in computer software. As high-speed digital networking evolved during the 1980s and 1990s, the ability to share this digital information both within and across organisations increased rapidly and created opportunities for collaboration in the development of defence systems.

The use of modelling and simulation (M\&S) within the defence acquisition system is a multi-dimensional activity which supports the milestone decision process, supports multiple stakeholders (operator, developer, designer, manufacturer, supporter, tester and trainer), and consists of various classes and types of $M \& S$, each with a specific purpose.

The Systems Engineering (SE) in the defence acquisition process is usually represented as a life-cycle with a series of stages as well as those mentioned above. The following sections resume the application of M\&S in a military system development context. ${ }^{19}$

19 Lalit K. Piplani, Systems Acquisition Manager's Guide for the Use of Models and Simulations, Report. Defense Technical Information Center, 1994. 


\section{Conceptual Design}

The conceptual design aims to arrive at a system-level design approach through tradeoff studies. While capability development processes are improving rapidly (based partly on improved $M \& S$ tools), little information is available on the design approach below system-level. Only broad concepts of operation, derived from the User Need, are known, implying, for example in a military system context, that Theatre/Campaign and Mission/ Battle models are used during this phase. As no actual equipment exists during this phase, constructive simulations are usually employed. The models used to describe behaviour are themselves process type models which of course do not have a physics base, but are rather based on doctrine, cognitive task analysis, psychological profiles and user experience. As such, this level of simulation is most useful for the exploration of concepts and possible behaviour before the design phase begins. If the simulation system is itself designed correctly, it can transition easily into the simulation tool needed for design phase support. A suite of models and simulations, along with supporting data including threat, environment, tactics, and others are required in this stage.

- Engineering level models of new designs provide system and subsystem performance to support higher-level models.

- Engagement and mission/battle level simulations evaluate the effectiveness of designs in an operational environment and evaluate the consequences of different engagement tactics.

- Campaign/theatre level models examine the outcomes of new system capabilities, technologies, and tactics in extended, combined force conflicts.

- Human interaction in simulations may be used either to identify the tactics for use in other models and simulations or to examine the operational impacts of alternative tactical schemes or concepts of operation.

- Virtual prototypes also demonstrate military utility of new tactics, technologies and systems.

This suite of models and simulations allows for analytical evaluation of tactics or concepts of operation changes with existing baseline systems before evaluation of new systems. The campaign/theatre level models and simulations, used in conjunction with the results of the lower-level models, will develop the data used to identify warfighting needs to be documented. The engagement and mission level models will identify the features and characteristics that provide the required capabilities with the potential to satisfy those needs.

\section{Preliminary Design}

The complexity of modern systems which involve numerous electronic subsystems and very rich information environments as well as the more traditional 'physical' components results in the need for a simulation system able to address a high degree of heterogeneity, and it is this fact which has led to the introduction of agent-based model techniques. The preliminary design aims to arrive at a sub-system-level design approach through trade-off studies. More information is available on most aspects of 
the overall design approach in this phase. The availability of this information implies that, again in a military system context, the same agent-based model used for concept development can be used by expanding the resolution of the various types of models used - Mission/Battle, Engagement, and Engineering type models.

These models have the same function as in the concept development phase but can represent these functions in more detail. Different analyses during this phase will require the models used to be of different levels of granularity depending on which elements of the system are being studied. The same behavioural models can also be carried forward to this phase, again with more detail if appropriate. Generally, it is expected that there is more of a focus on individual behaviours in this phase in contrast to unit-level behaviours in the concept development phase. Early prototyping during preliminary design would place greater emphasis on virtual simulations, which can often be readily developed from the components of the constructive agent-based simulation models. As this phase advances, it is expected that constructive and virtual models will be used together. However, the developmental nature of the early prototypes would preclude the use of live simulations.

\section{Detailed Design and Development}

Detailed design and development aim to arrive at a component-level design approach through trade-off studies. Detailed information will be available on all aspects of the design approach. The availability of this information implies that more detailed Engineering and Physics/Mathematics type models will be used in the simulation system replacing those used. Figure 8 presents a multi-physic simulation. Model and simulation performance can become an issue at this level. It is therefore essential to build the simulation system in such a way that it can be run with different levels of resolution in its different parts. Those components that do not understudy at any particular time must still be represented well enough so that the overall context is maintained, but at whatever lower level that is suitable to improve performance.

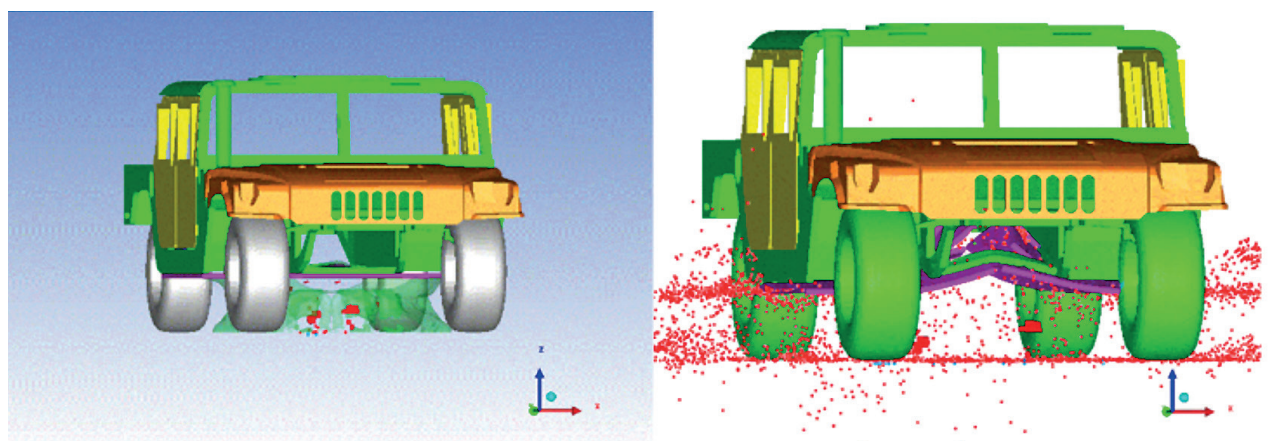

Figure 8

IED detonation simulation after $0.25 \mathrm{~ms}$ (left) and $0.9 \mathrm{~ms}$ (right) using ANSYS Autodyn software.

Source: Rodrigo Guajardo, 'Mecánica computacional como herramienta para el diseño de ingeniería de defensa', Academia Politécnica Militar-Boletín Científico 21 (2017), 43-66.

Available: http://boletincientifico.cl/boletines/boletin21/pdf/ARTICULO-3.pdf (13. 11. 2019.) 


\section{Production and Construction}

Production and/or construction aims to produce, integrate, and validate the system. A mix of Physics/Mathematics, Engineering, and Engagement type models would be used during production and/or construction. These hierarchical model types would take the form of process-based, physics-based and iconic models of high resolution and fidelity for satisfactory validation of the system, but which still exist with the agent-based simulation with this validation focus; the original constructive simulation becomes less critical, but still provides an integrating function, and should still be updated so that it can support further system evolution of functionality and complexity. Live and virtual simulations are used to validate both the real system and the constructive simulation models as presented in Figure 9, where a combat vehicle suspension is evaluated under current operational requirements.

\section{Utilisation and Support}

Utilisation and support will require the use of Physics/Mathematics, Engineering, Engagement, Mission/Battle, and Theatre/Campaign type models, which again can still be used from within the existing agent-based simulation system for system management purposes and for developing evolutionary additions to system functionality and exploring their consequences. Because the management function is more robust in this phase, some adaptation to the user interface will be required for usability reasons. However, in most cases, the same models can be used in earlier phases. Live and virtual simulations are also required for other functions, such as:

To validate the system or provide training to system users in operational scenarios that would otherwise be prohibitively complex, expensive, or dangerous, as the drop test simulation shown in Figure 10, that can report important design data as feedback.

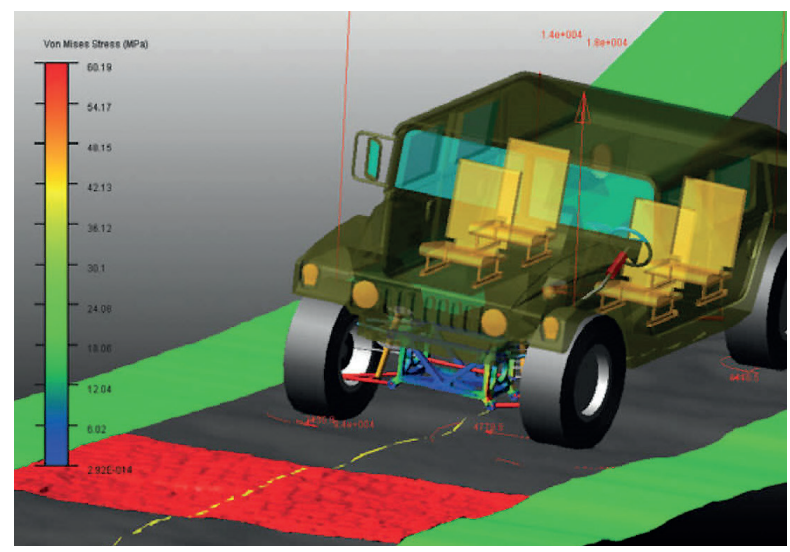

Figure 9

Virtual vehicle dynamics simulation performance assessment under environmental conditions using MSc Adams software.

Source: 'Dynamic analysis software Adams Car', Direct Industry. Available: www.directindustry.com/prod/mscsoftware/product-6042-1576633.html (08. 11. 2019.) 
To monitor the system's long-term performance for signs of degradation due to ageing, storage, or environmental factors.

To assess the effectiveness of the extant and modified system against emerging needs, using the five hierarchical model types.
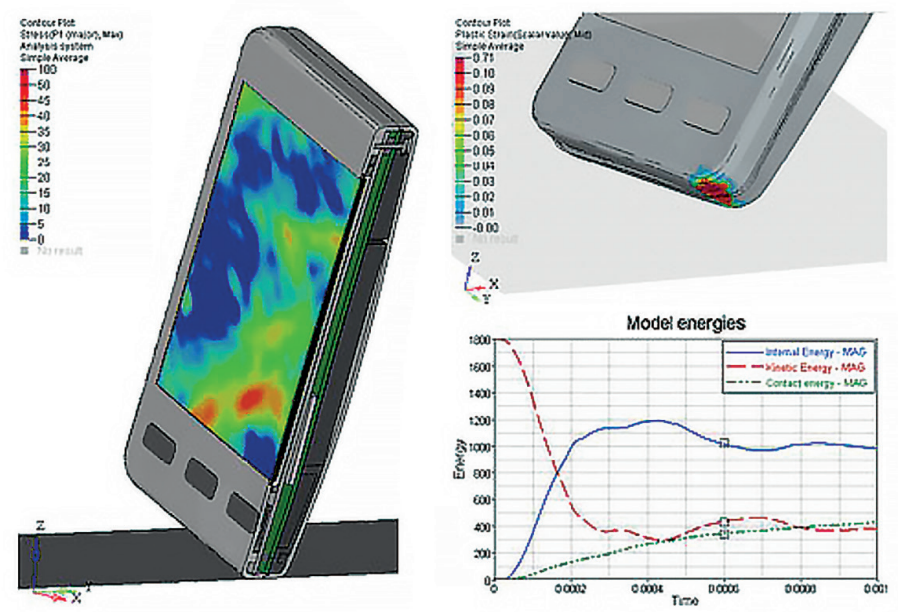

Figure 10

Drop test simulation capabilities using Altair Hyperworks software.

Source: 'Altair Radioss Overview', Altair. Available: https://altairhyperworks.com/product/RADIOSS (06. 10. 2019.)

\section{Disposal}

The final phase of disposal can also be facilitated by using M\&S. Components of the existing agent-based model will still be usable. However, the disposal will require the addition of new components dealing with possible secondary markets, financial issues relating to on-sales, financial issues relating to final disposal, environmental issues, and so on.

\section{Conclusions}

DoD Acquisition Modelling \& Simulation (M\&S) is usually not viewed by program managers as cost or schedule effective, although for systems engineers who have to deal with the development process of weapons systems it is an essential design tool. The potential for modelling and simulation tools and techniques to play a critical role in the development of military and general systems have by no means been exhausted. The study has shown that systems engineers now have at their disposal a comprehensive range of $M \& S$ tools and techniques to address all aspects of the systems engineering process. The technological evolution has made a transition from 
a complete absence of M\&S capability, with its consequent impact on the provision of cost-effective, reliable systems to meet user needs, through a position where the prevalence of digital computing leaves no excuse for the lack of effective M\&S. The key for systems engineers, however, is to be thoroughly familiar with the range of tools and techniques that are available (in other words, to possess so-called declarative knowledge relevant to $M \& S)$, and, necessarily, to understand when and why these tools and techniques can be applied in the development of complex systems. When these are brought together with a knowledge of how the tools and techniques are used (procedural knowledge), then systems engineers are fully equipped to make use of their knowledge and skills. This combination of the forms of knowledge is referred to as functioning knowledge and is seen as particularly necessary to the effective utilisation of modelling and simulation in systems engineering.

\section{References}

'About INCOSE', INCOSE. Available: www.incose.org. (24. 09. 2020.)

'Altair Radioss Overview'. Altair. Available: https://altairhyperworks.com/product/ RADIOSS (06. 10. 2019.)

Allouis, Elie - Blake, R. - Gunes-Lasnet, S. - Jorden, T. - Maddison, B. - Schroeven-Deceuninck, H. - Stuttard, M. - Truss, P. - Ward, K. - Ward, R. - Woods, M.: 'A Facility for the Verification \& Validation of Robotics \& Autonomy for Planetary Exploration'. Proceedings of the 12th Symposium on Advanced Space Technologies in Automation and Robotics. Noordwijk, ASTRA, 2013. Available: http://robotics. estec.esa.int/ASTRA/Astra2013/Papers/Allouis_2824264.pdf (28. 04. 2020.)

Buede, Dennis M.: The Engineering Design of Systems - Models and Methods. New Jersey, John Wiley \& Sons, 2009. DOI: https://doi.org/10.1002/9780470413791

'Department of Defense Instruction 5000.02 (DoDI)'. U.S. Department of Defense, Washington DC, 2015. Available: http://acqnotes.com/wp-content/uploads/2014/09/DoD-Instruction-5000.2-Operation-of-the-Adaptive-AcquisitionFramework-23-Jan-2020.pdf (15. 11. 2019.)

'Dynamic analysis software Adams Car'. Direct Industry. Available: www.directindustry. com/prod/msc-software/product-6042-1576633.html (08. 11. 2019.)

Guajardo, Rodrigo: 'Mecánica computacional como herramienta para el diseño de ingeniería de defensa'. Academia Politécnica Militar-Boletín Científico 21 (2017), 43-66. Available: http://boletincientifico.cl/boletines/boletin21/pdf/ARTICULO-3. pdf (13. 11. 2019.)

INCOSE - Systems Engineering Handbook: A Guide for System Life Cycle Processes and Activities, ed. by Walden, David D. New Jersey, John Wiley \& Sons, 2015.

Johnson, Stephen: 'Three approaches to big technology: Operations research, systems engineering, and project management'. Technology and Culture 38, no 4 (1997), 891-919. DOI: https://doi.org/10.2307/3106953

MIL-STD 499A:1974 Military Standard: Engineering Management, U.S., Department of Defense. Available: http://everyspec.com/MIL-STD/MIL-STD-0300-0499/ MIL-STD-499A_10375/ (11. 11. 2019.) 
Modeling and Simulation in Manufacturing and Defense Acquisition: Pathways to Success. National Research Council. Washington DC, The National Academies Press, 2002. DOI: https://doi.org/10.17226/10425

NATO AAP-48:2013 System Life Cycle Processes. Available: https://tssodyp.ssb. gov.tr/genel/ReferansDokumanlar/AAP48\%20NATO\%20System\%20Life $\% 20$ Cycle\%20Processes-Mart\%202013.pdf (15. 11. 2019.)

Piplani, Lalit K.: Systems Acquisition Manager's Guide for the Use of Models and Simulations. Report. Defense Technical Information Center, 1994. DOI: https:// doi.org/10.21236/ada285573 DOI: https://doi.org/10.21236/ADA285573

Systems Engineering Fundamentals. Supplementary Text Prepared by the Defense Acquisition University Press, Fort Belvoir, Virginia, January 2001. Available: https:// ocw.mit.edu/courses/aeronautics-and-astronautics/16-885j-aircraft-systems-engineering-fall-2005/readings/sefguide_01_01.pdf (24. 09. 2020.)

Systems Engineering Vision 2020. INCOSE, 2007. Available: www.ccose.org/media/ upload/SEVision2020_20071003_v2_03.pdf

The Acquisition Handbook. Ministry of Defence, 2002. Available: http://www.defence. org.cn/aspnet/vip-usa/uploadfiles/2004102932134509.pdf (11. 11. 2019.)

Welby, Stephen P.: 'Standards'. MES Journal 8 (2013), 2-3. Available: www.msco.mil/ DocumentLibrary/Journals/MSJournalSpring2013.pdf (15. 11. 2019.) 
